\title{
Copper Binding by Lactic Acid Bacteria (LAB)
}

\author{
Jasna Mrvčıć, Damir Stanzer*, Višnja BAČun-DružıNA and Vesna StehliK-TomaS \\ Faculty of Food Technology and Biotechnology, University of Zagreb, Pierottijeva 6, 10000 Zagreb, Croatia
}

Received July 18, 2008; Accepted October 24, 2008

\begin{abstract}
Western diet is frequently low in essential metal ions. A common method for preventing metal ion deficiency is pharmacological supplementation, especially in a highly available form such as metalo-protein complexes. Accordingly, in this work, specific lactic acid bacteria were assessed for their ability to bind copper ions. Significant amounts of copper ions were bound, and the binding potential was found to be strain specific. Differences among the strains were evaluated with the Langmuir model for biosorption. Binding of copper was a fast process, strongly influenced by ionic strength, pH and biomass concentration. During the process, copper ions significantly reduced cell viability. Discharge of copper ions in a simulated gastrointestinal tract was examined; 85-90\% of copper ions bound to LAB were discharged in the gastrointestinal model system.
\end{abstract}

Key words: copper; Lactobacillus; trace elements; lactic acid bacteria; gastrointestinal tract

\section{INTRODUCTION}

Trace elements are essential for many biochemical reactions. They act as a catalytic centre for enzymes or as an activator or stabilizer of the enzyme function (20). Also, the ionic species neutralize electrostatic forces present in various cellular anionic units, especially cell membranes and the double helix of DNA. It is well established that some trace elements, because of their involvement in conformation of antioxidant enzymes, may contribute to the prevention of oxidative stress $(18$, 24). Superoxide dismutase, catalase and glutathione peroxidase, which include cofactors $\mathrm{Cu}, \mathrm{Se}, \mathrm{Zn}, \mathrm{Mn}$ and $\mathrm{Fe}$, form a network of functionally overlapping defense mechanisms.

Copper is an essential element required by all living organisms. Copper works as an important cofactor for a variety of enzymes that are required for essential biochemical processes. However, $\mathrm{Cu}$ in excess is also highly toxic (22). It can participate in Fenton-like reactions that can generate extremely reactive hydroxyl radicals that can induce cellular damage (7). New publications note that the Western diet is frequently low in copper and, thus, closely associated with heart disease risk (21). Also, the roles of copper in the immune system, atherosclerosis, diabetes, rheumatoid arthritis and Parkinson's disease have not been well defined $(3,9,11$, 12).

Specific microorganisms are able to absorb numerous metal ions $(23,25)$, but this phenomenon has mainly been investigated from an environmental point of view

*Corresponding author. Mailing address: Faculty of Food Technology and Biotechnology, University of Zagreb, Pierottijeva 6 , 10000 Zagreb, Croatia. Phone: +385-1-4605030. Fax: +385-14605072. E-mail: dstanzer@pbf.hr
(13), and only soil bacteria, waste yeast and marine algae has been investigated. Usually, two processes take place: biosorption, the passive non-metabolically mediated process that may include adsorption, ion exchange, complexation, chelation and microprecipitation (1); and bioaccumulation, a slower metal-binding process which often follows biosorption, in which binding of metal ions with intracellular structures takes place (2).

In this study biosorption of copper ions by lactic acid bacteria (LAB) was investigated. LAB are nonpathogenic, food safe microorganisms, which are commonly used in the food industry to produce fermented foods. LAB are also part of a complex consortia of microorganisms in the human gastrointestinal tract. Many reports show the usefulness of LAB as probiotics for humans and animals, and have extensive physiological effects such as antimicrobial, immunomodulatory, anticarcinogenic, antidiarrheal, antiallergenic and antioxidant activities (17). It is well known that some species of LAB concentrate high levels of manganese (14). The potential of lactic acid bacteria to accumulate selenium, chromium and bind toxic ions of cadmium and lead has also been evaluated $(8,15,16,19)$. Protective effect of selenium-enriched lactobacilli on mice by elevating antioxidant-enzyme activities and reducing peroxidation reaction has been established (5). On the other hand, principles of copper binding by Lactobacillus species have not been established. Accordingly, the aim of this study was to examine a bioprocess for the production of copper-enriched LAB and to investigate in vitro the fate of copper enriched LAB in a gastrointestinal model system. 


\section{MATERIALS AND METHODS}

\section{Strains}

Throughout the study the following strains of LAB were used: Leuconostoc mesenteroides ID9261, Lactobacillus brevis ID 9262 and Lactobacillus plantarum ID9263. The strains were taken from the culture collection of the Faculty of Food Technology and Biotechnology, University of Zagreb, and identified for this work in the BCCM/LMG Bacteria Collection, Gent (Belgium). The stock culture was stored at $4{ }^{\circ} \mathrm{C}$ on MRS agar (Biolife) and was sub-cultured monthly. The selected strains were chosen because of their extensive use in food processing, especially in sourdough preparation. Bacteria were grown in microaerobic conditions at $32^{\circ} \mathrm{C}, 24 \mathrm{hr}$ in MRS broth (Biolife). Bacterial cells were separated from the culture medium by centrifugation $(5,000 \mathrm{rpm}, 20 \mathrm{~min})$ and washed twice with ultra pure water. This bacterial suspension was used in the copper binding experiments.

\section{Copper binding experiments}

The experiments were conducted in $300 \mathrm{ml}$ Erlenmeyer flasks containing $100 \mathrm{ml}$ of copper synthetic solutions in varying concentration, from 10 to $90 \mathrm{mg} / \mathrm{l}$. Metal ion solutions were prepared by diluting stock metal ion solution $(20 \mathrm{~g} / 1)$ which was obtained by dissolving $\mathrm{CuSO}_{4} \cdot 5 \mathrm{H}_{2} \mathrm{O}$ of analytical reagent grade (Merck) in redistilled water. LAB suspension was added to the copper solution to make a biomass concentration $0.5 \mathrm{~g} \mathrm{dcw} / 1$.

Negative controls contained bacteria in redistilled water and positive controls contained only copper in redistilled water. The flasks were agitated on a rotary shaker (Certomat, Braun, Germany) for $24 \mathrm{hr}$, at 100 $\mathrm{rpm}$. In the experiments for determination of $\mathrm{pH}$ effect on copper binding by LAB, the solution $\mathrm{pH}$ was adjusted with $\mathrm{HNO}_{3}$ and $\mathrm{NaOH}$, using a $\mathrm{pH}$ meter (Orion 720A, Thermo Electron Corporation, USA). During the copper binding process, survival of LAB was monitored by the pour plate method using MRS agar.

\section{Simulated gastric juice experiments}

Simulated gastric juice was prepared according to Charteris et al. (6). It was prepared by suspending pepsin from porcine gastric mucosa $(3 \mathrm{~g} / \mathrm{l})$ in sterile sodium chloride solution $(0.5 \%)$ and adjusting the $\mathrm{pH}$ to 2.5 with concentrated $\mathrm{HCl}$. Pepsin was obtained from SigmaAldrich. LAB cells prepared in the same way as for the binding experiments were resuspended in simulated gastric juice at a concentration $1 \mathrm{~g} \mathrm{dcw} / 1$. The incubation time was $4 \mathrm{hr}$.

Analysis of metal ions

After incubation, samples were taken from the suspension. The samples were centrifuged for $20 \mathrm{~min}$ at 5,000 rpm, and the supernatant fraction was analyzed for the remaining metal ions. One milliliter of supernatant was preserved with $10 \mathrm{ml} 1 \mathrm{~N} \mathrm{HNO}_{3}$ and the residual metal ion concentration was determined by a Flame Atomic Absorption Spectrophotometer (Spectra AA 300, Varian, USA). Whey powder (IAEA-155, International Atomic Energy Agency, Austria) was used as the commercial reference material.

\section{RESULTS}

Biosorption of copper ions with different strains of LAB was investigated as a function of different process parameters that can influence the metal ion binding process by microorganism. The influences of initial metal ion concentration, initial $\mathrm{pH}$, bacterial cell concentration and variation of temperature were examined. Also, binding of copper at different incubation times was monitored.

Assessment of copper binding capacity of different LAB strains was done by the Langmuir model (Fig. 1). This model is the model most frequently used to describe simple sorption isotherms and to compare the performance of different biosorbents. During the biosorption, a rapid equilibrium is established between adsorbed metal ions on the bacterial cell (qeq) and unadsorbed metal ions in solution $\left(\mathrm{C}_{\mathrm{eq}}\right)$. The Langmuir equation, that is valid for a monolayer sorption, is given below:

$$
\mathrm{q}_{\mathrm{eq}}=\mathrm{Q}_{\mathrm{o}} \mathrm{bC}_{\mathrm{eq}} /\left(1+\mathrm{bC}_{\mathrm{eq}}\right)
$$

where $\mathrm{q}_{\mathrm{eq}}$ is the specific metal ion binding $(\mathrm{mg} / \mathrm{g}$ biomass), $\mathrm{Q}_{\mathrm{o}}$ is the maximum amount of the metal ion per weight unit of bacteria to form a complete monolayer on the surface bound at high $\mathrm{C}_{\text {eq }}(\mathrm{mg} / \mathrm{g}), \mathrm{b}$ is a constant related to the affinity of the binding sites and $\mathrm{C}_{\mathrm{eq}}$ is the free concentration of metal ions at equilibrium. $\mathrm{Q}_{0}$ and $b$ can be determined from a linear plot of $\mathrm{C}_{\text {eq }} / \mathrm{q}$ eq vs. $\mathrm{C}_{\text {eq }}$.

Table 1. Langmuir model parameters for the binding isotherms of copper by probiotic bacteria in aqueous solutions

\begin{tabular}{lccc}
\hline \multicolumn{1}{c}{ Bacterium } & $\mathrm{Q}_{\mathrm{o}}$ & $\mathrm{b}$ & $\mathrm{R}^{2}$ \\
\hline L. mesenteroides & $26.25 \pm 1.0$ & $1.06 \pm 0.08$ & 0.9989 \\
L. brevis & $26.52 \pm 1.7$ & $1.17 \pm 0.1$ & 0.9984 \\
L. plantarum & $15.53 \pm 0.8$ & $2.70 \pm 0.06$ & 0.9999
\end{tabular}

$\mathrm{Q}_{\mathrm{o}}$ : maximum binding capacity, b: affinity between the sorbent and the sorbate. 




Fig. 1. Langmuir isotherms for copper binding by LAB (black markers: experimental data, white markers: model).

The binding isotherms were generated for all strains tested (Fig. 1) and the estimated model parameters are shown in Table 1.

The data were found to fit the Langmuir model with a high goodness of fit, expressed by high $\mathrm{R}^{2}$ values. $\mathrm{Q}_{\mathrm{o}}$ values of $L$. mesenteroides and L. brevis were high, indicating high binding efficiency for copper binding. For this reason these strains were chosen for further study. Also, it was noticeable that the absorption was copper ion concentration dependent for all strains tested, with less binding achieved at higher initial copper ion concentrations.

Earlier studies on metal ion biosorption have shown that the $\mathrm{pH}$ value is the most important parameter affecting the biosorption process $(13,23)$. The results presented in Fig. 2 support this assumption - the initial $\mathrm{pH}$ solution significantly affected the copper binding by L. mesenteroides and L. brevis $(p \leq 0.05)$. At low $\mathrm{pH}$ $(\mathrm{pH}<3)$ copper ion binding was negligible, but it increased with initial ambient $\mathrm{pH}$ value increase. At low $\mathrm{pH}$ values, the affinity of the cell wall for metal ions decreases, presumably due to competition with $\mathrm{H}^{+}$ions for the binding sites. Enhanced adsorption at higher $\mathrm{pH}$ could be due to increases in the negative charge of surface functional groups.

The effect of bacterial biomass concentration on the adsorbed copper ion is shown in Fig. 3. The results show that bacterial concentration strongly affected the amount of copper ion bound. Higher concentrations of bacterial biomass increased the amount of copper bound to bacterial biomass. The binding of the copper was found to follow linear pattern. Reports in the literature show that increasing the amount of added biosorbent increased the amount of bound metal ions (15), although some

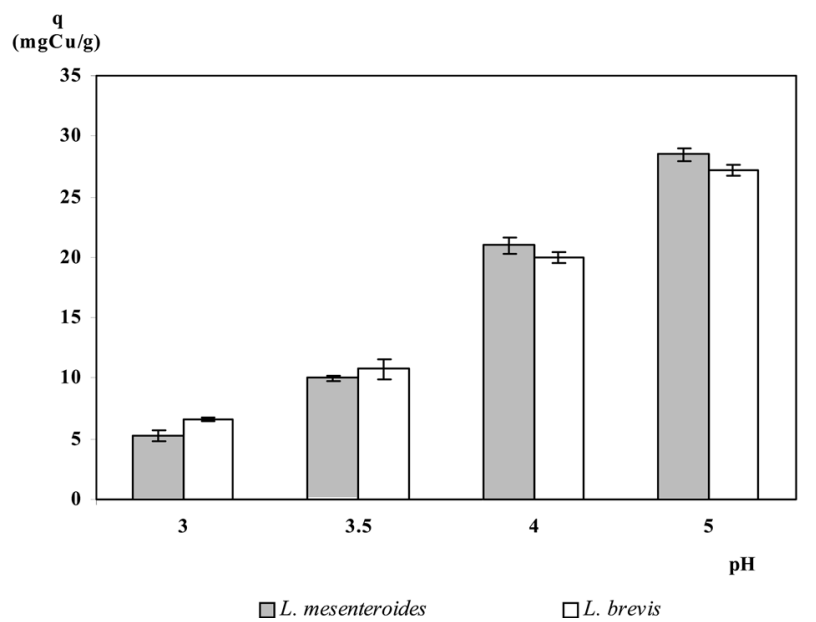

Fig. 2. Influence of aqueous solution $\mathrm{pH}$ on copper binding by $L$. mesenteroides and L. brevis after $24 \mathrm{hr}$ at $32^{\circ} \mathrm{C}$ and initial copper concentration of $20 \mathrm{mg} / \mathrm{l}$.

$\mathrm{Cu}$ bound (\%)

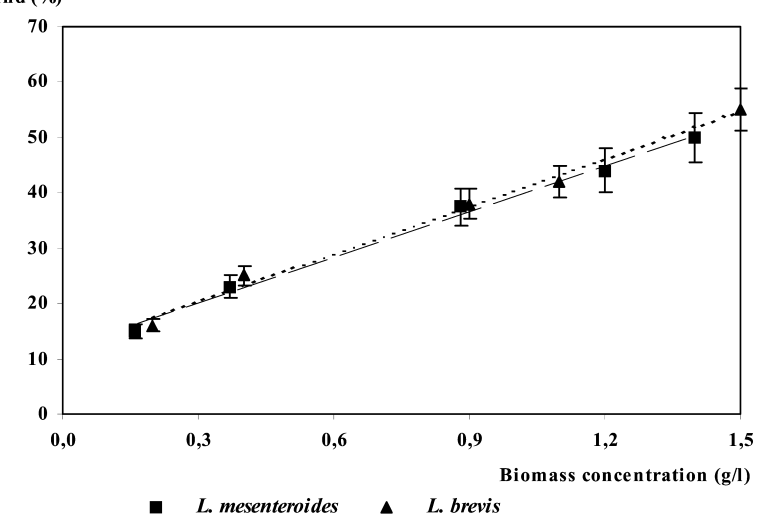

Fig. 3. Influence of biomass concentration on copper binding by L. mesenteroides and L. brevis after $24 \mathrm{hr}$ at $32^{\circ} \mathrm{C}$, and initial copper concentration of $50 \mathrm{mg} / \mathrm{l}$.

authors have reported that aggregates formed during biosorption at higher biomass concentrations reducing the efficiency of adsorption (4).

Although some authors have reported increases of metal ions binding with temperature increase due to the influence of temperature on the stability of the metalmicroorganism complex and the ionization of chemical moieties on the cell wall (15), biosorption is defined as the initial rapid accumulation step in metal ion binding that is metabolism and temperature independent (1).

Copper binding in aqueous solution by $L$. mesenteroides and L. brevis after $24 \mathrm{hr}$ at different incubation temperatures is shown in Fig. 4. The results confirm the assumption about the independence of 


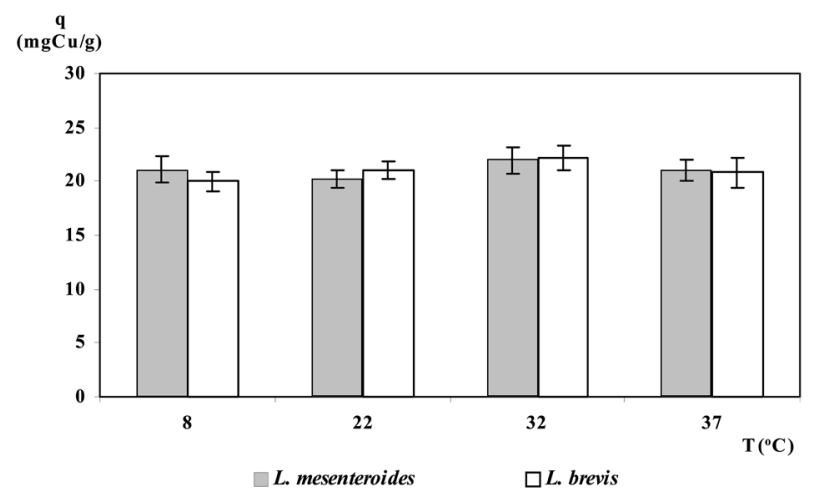

Fig. 4. Influence of temperature on copper binding by $L$. mesenteroides and L. brevis after $24 \mathrm{hr}$, and initial copper concentration of $20 \mathrm{mg} / 1$.

biosorption from temperature, since the amount of copper ions binding to biomass at 4 different temperatures was the same.

The results presented in Fig. 5 show that copper ion binding consisted of two phases: a fast initial phase, within the first $3 \mathrm{hr}$, and a slower secondary phase. During the first phase the major part of the copper ions were bound (about $65 \%$ ). However, upon prolonged incubation more copper was bound. Thus, copper ion binding appears to involve not only the cell wall, but also intracellular.

Although copper is an essential cofactor of many enzymes, it is toxic at high concentrations. Because of this, the survival of LAB during the copper binding process was monitored at different initial copper

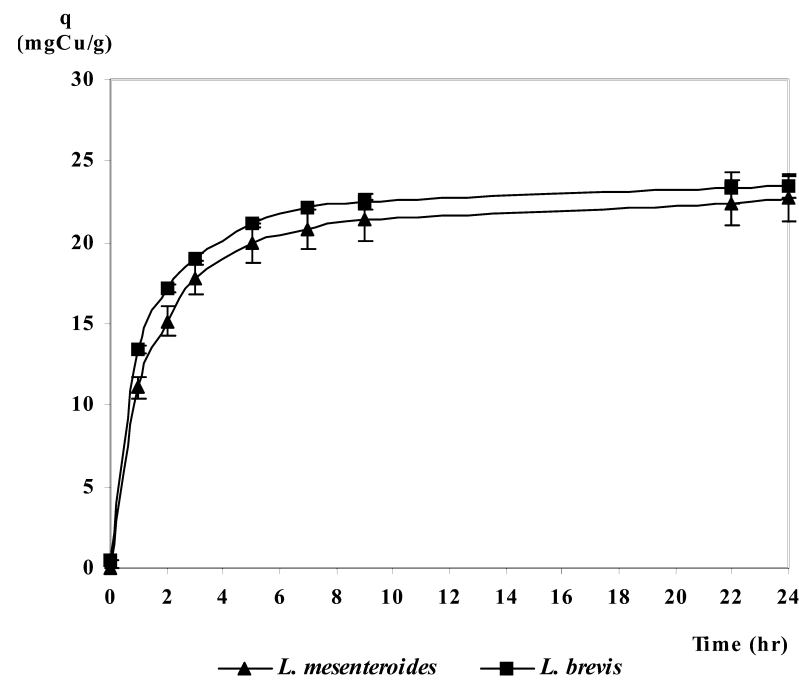

Fig. 5. Copper binding from aqueous solution (20 mg/l) by $L$. mesenteroides and $L$. brevis at different incubation times. concentrations. The results are presented in Fig. 6. Copper significantly reduced cell viability, especially $L$. plantarum cells. After $24 \mathrm{hr}$ the number of live cells was negligible for all strains tested at both copper concentrations. After $3 \mathrm{hr}$ of the process the concentration of viable cells was about $1 \times 10^{6} \mathrm{CFU} / \mathrm{ml}$ for L. mesenteroides and L. brevis at $20 \mathrm{mg} / 1$ initial copper concentration.

LAB enriched with copper could be a valuable source of this element in food, because organic state metal ions (metalloproteins or bioplexes) are easily and safely absorbed by humans, and their absorption rates are higher than their inorganic states (10). The sites of copper ion absorption are the stomach and duodenum (24). Therefore, we examined the discharge of copper ions in a gastrointestinal model system. Difficulties involved in studying bacterial properties in the gastrointestinal tract, especially in humans, have led to the development of different model systems that simulate gastrointestinal tract. The release of copper ions from $\mathrm{LAB}$ after $4 \mathrm{hr}$ incubation in simulated gastric juice is presented in Fig. 7. The bond of $\mathrm{LAB}$ and copper ions was unstable. Over $4 \mathrm{hr}$ of incubation $85-90 \%$ of copper ions were discharged from LAB, apparently due to a low $\mathrm{pH}$ value.

\section{DISCUSSION}

A common method for preventing metal ion deficiency is pharmacological supplementation, especially through the highly available form of metaloprotein complexes. Therefore, the ability of LAB to bind trace elements, such as copper, could have considerable potential use. Human copper deficiency has been reported in association with generalized malnutrition and prolonged diarrhea in infants and children, intestinal malabsorption syndromes, jejunostomy and biliary losses, Menke's kinky hair syndrome and patients maintained on prolonged parenteral nutrition without copper supplements (24). Optimal concentration of copper ions in the body is of critical importance, especially in combination with LAB, the positive effect of which on peoples health is invaluable (17). The results presented in this work demonstrate that copper ions can be successfully bound by L. mesenteroides and L. brevis, whereas L. plantarum has a minor biosorption capacity. Differences between bacterial strains in metal ion binding capacity may be due to properties of the bacteria (structure, functional groups and surface area, depending on the bacterial division, genera and species). Treatment of bacterial biomass with heating or exposure to acid or base can enhance metal ion binding by microorganisms, 
A

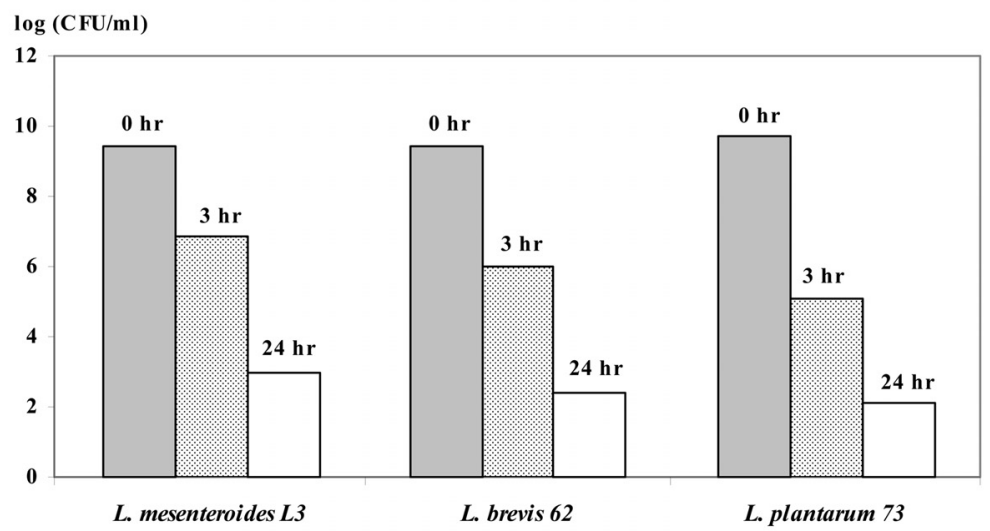

B

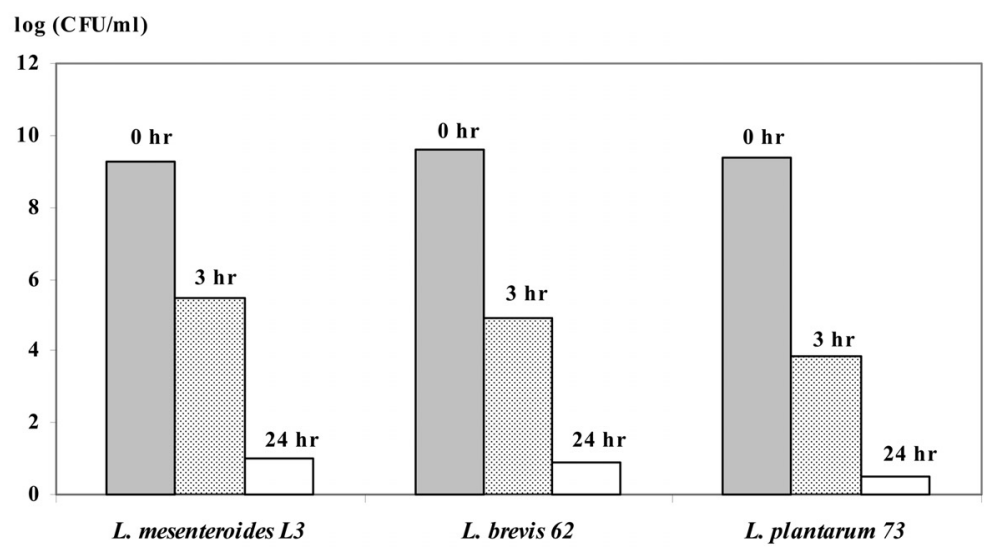

Fig. 6. Comparison of the survival of LAB during the copper binding process among different initial copper concentrations (A: $20 \mathrm{mg} / 1$, and B: $50 \mathrm{mg} / \mathrm{l}$ ).

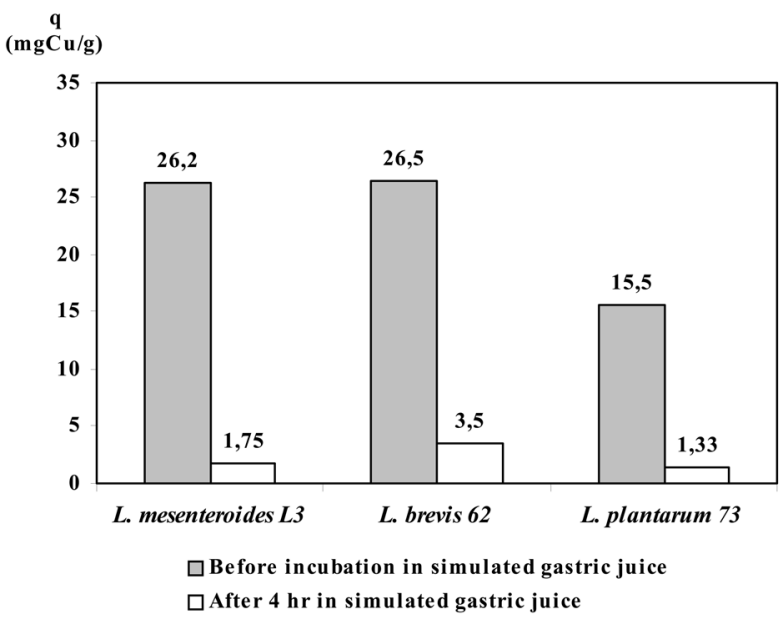

Fig. 7. Discharge of copper ions from LAB in a gastrointestinal model system. due to increase in the number of metal binding sites of the cell wall $(15,16,19)$. However, in this work the supplementation of LAB with copper was performed in order to produce probiotic (active) biomass. For this reason the possibility of bacterial biomass pretreatment was excluded.

Process parameters such as initial metal ion concentration, initial $\mathrm{pH}$ and bacterial cell concentration influenced the copper ion binding process by LAB. Exposure of bacterial cell to copper ions especially influenced cell viability. As we can see from Fig. 6, copper was highly toxic and it significantly reduced cell viability. Contact time examination (Fig. 5) for copper binding by LAB shows that copper ion binding consisted of two phases, an initial rapid copper binding within the first $3 \mathrm{hr}$ and a slower secondary phase. Within the first 3 $\mathrm{hr}$, the major part of copper ions was bound. In the media with an initial copper concentration of $20 \mathrm{mg} / 1$ the number of live $L$. mesenteroides and $L$. brevis cells after 
$3 \mathrm{hr}$ of incubation was about $1 \times 10^{6} \mathrm{CFU} / \mathrm{ml}$. From our result, it can be concluded that for active copper enriched LAB production, the initial copper ions concentration should be no higher than $20 \mathrm{mg} / \mathrm{l}$ and that the incubation time should not exceed $3 \mathrm{hr}$.

Our study of the behavior of copper-enriched LAB in simulated gastric juice clearly shows that under the conditions of the gastrointestinal model the release of copper ions from bacterial biomass takes place. Since copper ion absorption starts in the stomach, this fact offers the possibility of copper-enriched LAB application as a valuable source of human copper supplementation.

Acknowledgements. The authors are grateful for financial support from The Ministry of Science and Technology of the Republic Croatia.

\section{REFERENCES}

(1) Blackwell KJ, Singleton I, Tobin JM. 1995. Metal cation uptake by yeast: a review. Appl Microbiol Biotechnol 43: 579-584.

(2) Brady D, Duncan JR. 1994. Binding of heavy metals by the cell walls of $S$. cerevisiae. Enzyme Microb Technol 16: 633-638.

(3) Bull PC, Cox DW. 1994. Wilson disease and Menkes disease: new handles on heavy-metal transport. Trends Genet 10: 246-252.

(4) Cabuk A, Akar T, Tunali S, Gedikli S. 2007. Biosorption of $\mathrm{Pb}(\mathrm{II})$ by industrial strain of Saccharomyces cerevisiae immobilized on the biomatrix of cone biomass of Pinus nigra: equilibrium and mechanism analysis. Chem Eng J. 131: 293-300.

(5) Chen L, Pan D, Zhou J, Jiang YZ. 2005. Protective effect of selenium-enriched lactobacillus on CCl4induced liver injury in mice and it mechanisms. World J Gastroenterol 11: 5795-5800.

(6) Charteris WP, Kelly PM, Morelli L, Collins JK. 1998. Development and application of an in vitro methodology to determine the transit tolerance of potential probiotic Lactobacillus and Bifidobacterium species in the upper human gastrointestinal tract. $\mathbf{J}$ Appl Microbiol 84: 759-768.

(7) Cizewski V, Klomp LWJ, Strain J, Casareno RLB. 1997. The copper chaperone for superoxide dismutase. J Biol Chem 272: 23469-23472.

(8) Diowksz A, Ambroziak W, Wlodarczyk M., 1999. Investigation of the ability of selenium accumulation by lactic acid bacteria of Lactobacillus species and yeast Saccharomyces cerevisiae. Pol J Food Nutr Sci 8: 17-21.

(9) DiSilvestro RA. 1992. Effects of copper supplementation on ceruloplasmin and copper superoxide dismutase in free-living rheumatoid arthritis patients. J Am Coll Nutr 11: 177-180.

(10) Dobrzanski Z, Jamroz D. 2003. Bioavailability of selenium and zinc supplied to the feed for laying hens in organic and inorganic form. EJPAU 6: 1-8.

(11) Failla ML, Hopkins RG. 1998. Is low copper status immunosuppressive? Nutr Rew 56: 59-64.

(12) Gerson C. 1998 The role of copper, molybdenum, selenium, and zinc in nutrition and health. Clin Lab Med 18: 673-685.

(13) Godlewska-Zlkiewicz B. 2006. Microorganisms in inorganic chemical analysis. Anal Bioanal Chem 384: 114-123.

(14) Groot MNN, Klaassens E, de Vos WM, Delcour J, Hols P, Kleerebezem M. 2005. Genome-based in silico detection of putative manganese transport systems in Lactobacillus plantarum and their genetic analysis. Microbiology 151: 1229-1238.

(15) Halttunen T, Kankaanpaa P, Tahvonen R, Salminen S, Ouwehand AC. 2003. Cadmium removal by specific lactic acid bacteria. Biosci Microflora 22: 93-97.

(16) Halttunen T, Salminen S, Tahvonen R. 2007. Rapid removal of lead and cadmium from water by specific lactic acid bacteria. Int J Food Microbiol 114: 30-35.

(17) Havenaar R, Huis in’t Veld JHJ. 1992. Probiotics: a general view. In The Lactic Acid Bacteria, Vol. 1: The Lactic Acid Bacteria in Health and Disease, Wood BJB (ed), Chapman \& Hall New York, NY, p.209-224.

(18) Heyland DK, Dhaliwal R, Suchner U, Berger MM. 2005. Antioxidant nutrients: a systematic review of trace elements and vitamins in the critically ill patient. Intensive Care Med 31: 327-337.

(19) Ibrahim F, Halttunen T, Tahvonen R, Salminen S. 2006. Probiotic bacteria as potential detoxification tools: assessing their heavy metal binding isotherms. Can J Microbiol 52: 877-885.

(20) Jones RP, Gadd GM. 1990. Ionic nutrition of yeastphysiological mechanisms involved and implications for biotechnology. Enzyme Microb Technol 12: 402 418.

(21) Klevay LM. 2000. Cardiovascular disease from copper deficiency - a history. J Nutr 130: 489-492.

(22) Mrvcic J, Stehlik-Tomas V, Grba S. 2008. Incorporation of copper ions by yeast Kluyveromyces marxianus during cultivation on whey. Acta Aliment 37: 133-139.

(23) Mrvcic J, Stanzer D, Stehlik-Tomas V, Skevin D, Grba S. 2007. Optimization of bioprocess for production of copper-enriched biomass of industrially important microorganism Saccharomyces cerevisiae. J Biosci Bioeng 103: 331-337.

(24) Simić D, Budić I. 2003. Trace elements. Acta Fać Med Naiss 20: 189-202.

(25) Stehlik-Tomas V, Grba S, Stanzer D, Vahčic N, Gulan-Zetić V. 2003. Uptake of iron by yeast cells and its impact on biomass production. Acta Aliment 32: 279-287. 